\title{
High electrochemical performance of hierarchical porous activated carbon derived from lightweight cork (Quercus Suber)
}

Faith O. Ochai-Ejeh, ${ }^{\mathrm{a}}$ Abdulhakeem Bello, ${ }^{\mathrm{a}}$ Julien Dangbegnon, ${ }^{\mathrm{a}}$ Abubakar Abubakar Khaleed, ${ }^{\mathrm{a}}$ Moshawe Jack Madito, ${ }^{\mathrm{a}}$ Farshad Bazegar ${ }^{\mathrm{a}}$ and Ncholu Manyala ${ }^{\mathrm{a} *}$

\footnotetext{
${ }^{a}$ Department of Physics, Institute of Applied Materials, SARChi Chair in Carbon Technology and Materials, University of Pretoria, Pretoria 0028, South Africa.

*Corresponding author’s email: ncholu.manyala@up.ac.za, Tel.: + (27)12 420 3549; Fax: + (27)12 4202516
}

The e-mail addresses of all authors:

Faith O. Ochai-Ejeh: faithukamaka@gmail.com

Abdulhakeem Bello: bellohakeem@gmail.com

Julien Dangbegnon: dangbegnon01@gmail.com

Abubakar Abubakar Khaleed: abubakarkhaleed2@gmail.com

Moshawe Jack Madito: jack.madito@gmail.com

Farshad Bazegar: farshadbarzegar@gmail.com

Ncholu Manyala: ncholu.manyala@up.ac.za 


\section{ABSTRACT}

Activated carbon (AC) derived from biomass lightweight cork (Quercus Suber) material was synthesized by $\mathrm{KOH}$ activation with different mass ratios of Quercus Suber:KOH in order to investigate the electrochemical properties of the $\mathrm{AC}$ in relation to $\mathrm{KOH}$ concentration. A welldefined porous activated carbon was obtained with a high surface area of $1081 \mathrm{~m}^{2} \mathrm{~g}^{-1}$ and a high pore volume of $0.66 \mathrm{~cm}^{3} \mathrm{~g}^{-1}$ when the Quercus Suber:KOH mass ratio was fixed at 1:2. A specific capacitance of $166 \mathrm{~F} \mathrm{~g}^{-1}$ was obtained for the symmetric device at $0.5 \mathrm{~A} \mathrm{~g}^{-1}$ in $1 \mathrm{M}$ $\mathrm{Na}_{2} \mathrm{SO}_{4}$ with energy and power densities of $18.6 \mathrm{~W} \mathrm{~h} \mathrm{Kg}^{-1}$ and $449.4 \mathrm{~W} \mathrm{Kg}^{-1}$ respectively. The device displays good cycling stability after floating test for $200 \mathrm{~h}$ at $1.8 \mathrm{~V}$ and also displaying $99.8 \%$ capacitance retention after cycling for 5000 cycles. The excellent electrochemical performance of the device makes it a potential material for supercapacitor application.

KEYWORDS: Activated carbon; Porous structure; Specific capacitance; Energy density; Supercapacitor; Biomass

\section{INTRODUCTION}

Dealing with the present day energy crisis such as providing sustainable and renewable energy for present and future needs is a major challenge globally. This is as a result of the diminution in the supply of fossil fuel and the deteriorating environmental impact of conventional energy storage technologies, such as batteries which make use of very toxic chemicals like lead and lithium ion which are flammable. Therefore, there is an urgent need for environment-friendly energy storage devices from renewable and sustainable sources to address this need [1-7].

Supercapacitors (SCs) also known as electrochemical capacitors have become desirable as energy storage devices because they offer numerous prospects of being low cost and make use of cheap, abundant and renewable raw materials with promising advantages of operating at high power density with excellent reversibility, oscillatory power supply, long cycle life with fast charging and high-powered charge production [8-10]. The categories of SCs are electric double layer capacitors (EDLCs), pseudocapacitors and faradaic SCs. EDLCs are a class of SCs which store charges electrostatically by reversible absorption/desorption of ions at the electrode- 
electrolyte interface of the active material, which is largely dependent on the structure and morphology of the material $[1,7,11,12]$. Pseudocapacitors are capacitors that have electrochemical behavior similar to that of EDLC electrodes but in which the charge transfer originates from the electron transfer mechanism rather than on the accumulation of ions in the electrochemical double layer, while faradaic capacitors store charges by rapid redox reactions at the surface of active material [11]. Several SC materials have been explored as potential materials for SC application such as carbonaceous materials, conducting polymers and transition metals. Carbonaceous materials such as graphene, carbon nanotubes and activated carbon (AC) are usually used for EDLCs because of their excellent electronic conductivity, good pore size distribution, and large specific surface areas. However, most of the available SCs still suffer from low energy densities when compared to that of batteries. Therefore, research to improve the energy density of SCs is paramount. The electrode material and the electrolyte are the key components that determine the electrochemical performance of SCs $[1,2,13]$. Since energy density $\left(E_{d}\right)$ is proportional to specific capacitance $\left(C_{\mathrm{sp}}\right)$ and the square of potential window $\left(E_{d} \sim C_{s p} V^{2}\right)$ of the electrode material, the research focus is on enhancing the property of the materials by researching on ways to improve on the potential window and / or the specific capacitance of the materials [14-16].

The efforts have been made in the in the previous studies along this line to improve the working potential and specific capacitance of SCs. For instance, a symmetric carbon/carbon SC with a $C_{\mathrm{sp}}$ of $115 \mathrm{~F} \mathrm{~g}^{-1}$ operating at $1.6 \mathrm{~V}$ in $\mathrm{Na}_{2} \mathrm{SO}_{4}$ was reported [16]. Similarly, a report on SWNT electrodes with a $C_{\mathrm{sp}}$ of $180 \mathrm{~F} \mathrm{~g}^{-1}$ was obtained at $1.0 \mathrm{~V}$ in $\mathrm{KOH}$ electrolyte [17]. In another study on $\mathrm{Ni}(\mathrm{OH})_{2} /$ graphene and $\mathrm{RuO}_{2} /$ graphene, a $C_{\text {sp }}$ of $\sim 153 \mathrm{~F} \mathrm{~g}^{-1}$ was obtained at a potential window of $1.6 \mathrm{~V}$ in $\mathrm{KOH}$ aqueous electrolyte [18], an asymmetric SC based on Graphene $/ \mathrm{MnO}_{2}$ and $\mathrm{AC}$ Nanofiber was also reported with a $C_{\text {sp }}$ of $113.5 \mathrm{~F} \mathrm{~g}^{-1}$ at $1.8 \mathrm{~V}$ in $\mathrm{Na}_{2} \mathrm{SO}_{4}$ [19]. A study on the Unequalization of the electrode capacitance indicated a considerable increase in the working potential of a symmetric $\mathrm{SC}$ (up to $1.9 \mathrm{~V}$ ) in aqueous $\mathrm{K}_{2} \mathrm{SO}_{4}$ with a $C_{\mathrm{sp}}$ of $80 \mathrm{~F} \mathrm{~g}^{-1}[1,14,16]$. There have been reports on several studies on the fabrication of electrode materials from AC with good pore size distribution, large specific surface area, good conductivities and high specific capacitances. However, their industrial and large-scale production have been limited by high cost and degree of the corrosiveness of the materials utilized in the fabrication $[16,20]$. 
The use of abundant and renewable, cost effective, lightweight materials with tunable porosity that are efficient, sustainable and environmentally safe is still imperative due to the high cost involved in the production of some materials listed above. Also, the utilization of the same material for both the positive and negative electrode is essentially important both in terms of cost and large scale production [3,14, 20-24]. Biomass trials for the production of AC have become attractive because they are low-cost source of carbon material with tunable properties; hence have been recently explored for SCs. Another important factor to consider is the electrolytes used in the device fabrication. Alkaline, acidic/ionic electrolytes usually have high conductivity which makes them achieve high $C_{\mathrm{sp}}$ but they suffer from low $E_{d}$ because of inability to operate at large potential windows. This is because thermodynamically, the decomposition of water is at $1.23 \mathrm{~V}$. Neutral electrolytes can attain moderate potential windows leading to better electrochemical performance. Organic electrolytes, however, have large operating potential windows but are toxic, have poor electrical conductivity and are quite expensive. Hence, neutral electrolytes are preferred due to their advantage of enhancing SC performance [25, 26].

In a report on SC from sunflower seed shell, a $C_{\mathrm{sp}}$ of $311 \mathrm{~F} \mathrm{~g}^{-1}$ was obtained in a potential window of $0.9 \mathrm{~V}$ in $3 \mathrm{M} \mathrm{KOH}$ electrolyte [27]. In a study of mesoporous carbon from coconut shell, a $C_{\mathrm{sp}}$ of $246 \mathrm{~F} \mathrm{~g}^{-1}$ was obtained within a voltage window of $0.7 \mathrm{~V}$ in $0.5 \mathrm{M} \mathrm{H}_{2} \mathrm{SO}_{4}$ [28] and in another report on SC electrode derived from coconut leaves, a $C_{\mathrm{sp}}$ of $133 \mathrm{~F} \mathrm{~g}^{-1}$ was obtained in a potential window of $1.0 \mathrm{~V}$ in $6 \mathrm{M} \mathrm{KOH} \mathrm{[29].} \mathrm{Also,} \mathrm{in} \mathrm{a} \mathrm{study} \mathrm{on} \mathrm{Pistachio} \mathrm{nutshells} \mathrm{derived}$ carbon, a $C_{\mathrm{sp}}$ of $261 \mathrm{~F} \mathrm{~g}^{-1}$ was obtained in a potential window of $1.1 \mathrm{~V}$ in $6 \mathrm{M} \mathrm{KOH} \mathrm{[30].} \mathrm{These}$ devices have been reported with high capacitance values but the nature of the electrolytes used and the working potential of the device results to low $E_{d}$, and therefore limits their industrial application $[16,31]$.

In this study, we present a carbon-carbon symmetric supercapacitor with good electrical conductivity and specific capacitance with a working voltage of $1.8 \mathrm{~V}$ in $1 \mathrm{M} \mathrm{Na}_{2} \mathrm{SO}_{4}$. The device is produced from cheap and light weight material Cork (Quercus Suber), a spongy material which comes from the bark of an evergreen oak tree. The renewability and sustainability of this material make it a choice material for this study. $1 \mathrm{M} \mathrm{Na}_{2} \mathrm{SO}_{4}$ was chosen for this study because it has been demonstrated that a stable potential window of up to $2 \mathrm{~V}$ can be achieved in a carbon - carbon SC in the neutral electrolyte. Another factor considered was that it is less toxic and corrosive when compared to the acidic electrolytes $[1,14,16]$. The choice of $\mathrm{KOH}$ as the 
activation agent is as a result of the fact that it can be used to produce ACs with well-defined micropores and mesopores with tunable porosity, however, a systematic study was astutely carried out because of the corrosive nature of $\mathrm{KOH}$ considering the economic and environmental impact of materials produced [20, 24].

\section{EXPERIMENTAL}

\subsection{Material synthesis}

The cork raw material used for this study was collected from Algeria and used for the production of activated carbon. Scheme 1 shows the complete synthesis route of the activated carbon. $5 \mathrm{~g}$ of the raw material was impregnated with $\mathrm{KOH}$ in the ratio of 1:1, 1:2 and 1:3, left for $72 \mathrm{~h}$ for the material to properly absorb the $\mathrm{KOH}$ before drying it in the oven at $60{ }^{\circ} \mathrm{C}$ for several hours. The samples were then carbonized at $800{ }^{\circ} \mathrm{C}$ under argon flow $(300 \mathrm{sccm})$ for $2 \mathrm{~h}$. The black material obtained after carbonization was washed with $3 \mathrm{M} \mathrm{HCl}$, and deionized water until the filtrate became neutral to a $\mathrm{pH}$ indicator. The obtained activated carbon with porous structure (see micrograph image in Scheme 1) was denoted as AC KOH 1, AC KOH 2 and AC $\mathrm{KOH} 3$ for raw material: $\mathrm{KOH}$ mass ratios of 1:1, 1:2 and 1:3 respectively.

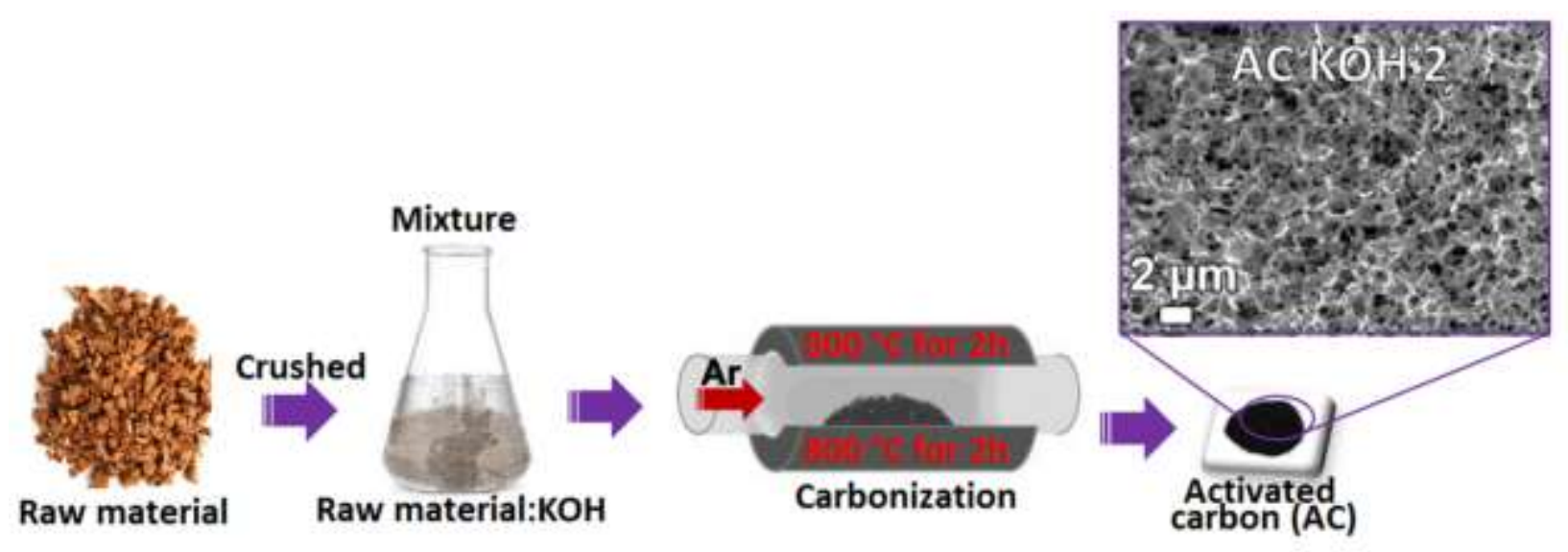

Scheme 1 Schematic of the synthesis route of the activated carbon which are denoted as AC $\mathrm{KOH} 1, \mathrm{AC} \mathrm{KOH} 2$ and $\mathrm{AC} \mathrm{KOH} 3$. 


\subsection{Structural, morphological and composition characterization}

X-ray Diffraction (XRD) studies were carried out using XPERT-PRO diffractometer (PANalytical BV the Netherlands) while Raman analysis was carried out using a Jobin-Yvon Horiba TX 64000 micro-spectrometer. Scanning electron microscopy (SEM) and energy dispersive X-ray spectroscopy (EDS) analysis were carried out using Zeiss Ultra plus 55 field emission scanning electron microscope (FE-SEM) at an accelerating voltage of $2.0 \mathrm{kV}$. Highresolution transmission electron microscopy (HRTEM) analysis was carried out using a Jeol$2100 \mathrm{~F}$ field emission electron microscope operated at $200 \mathrm{kV}$ with a probe size of $<0.5 \mathrm{~nm}$. The $\mathrm{N}_{2}$ adsorption/desorption isotherm measurements were carried out with a Micrometrics TriStar II 3020 .

\subsection{Electrochemical measurements}

The AC samples were tested in three- and two-electrode configurations in a multichannel VMP300 potentiostat/galvanostat (Biologic, France) workstation at ambient temperature. The electrodes for the three-electrode measurement were fabricated by preparing a homogeneous mixture of the activated carbon material ( $80 \mathrm{wt}$. \%), carbon black (15 wt. \%) to enhance the conductivity of the material and polyvinylidene difluoride (PVdF) (5 wt. \%) as a binder in an agate mortar. A paste was made from the above mixture by adding 1-methyl-2-pyrrolidinone (NMP) drop-wise to the mixture and then coated on $2 \mathrm{~cm} \times 2 \mathrm{~cm}$ nickel foam current collectors. The coated samples were then dried in an oven at $60{ }^{\circ} \mathrm{C}$ overnight. The symmetric device for the two-electrode measurements was similarly fabricated but was coated and pressed on $16 \mathrm{~mm}$ diameter nickel foams dried at $60{ }^{\circ} \mathrm{C}$ overnight and then assembled in a coin cell with a microfiber glass filter paper as a separator. The preliminary test was performed in $1 \mathrm{M} \mathrm{Na}_{2} \mathrm{SO}_{4}, 1$ $\mathrm{M} \mathrm{NaNO}_{3}$ and $1 \mathrm{M} \mathrm{Li}_{2} \mathrm{SO}_{4}$ aqueous electrolytes with glassy carbon and $\mathrm{Ag} / \mathrm{AgCl}$ as counter and reference electrodes respectively. The specific capacitance for the single electrode was calculated from the charge discharge using Eq. 1 [32]

$C_{s p}\left(\mathrm{Fg}^{-1}\right)=4 I \Delta t / m \Delta U$

where $I(\mathrm{~A})$ is the current, $\Delta t(\mathrm{~s})$ is the discharge time, $\Delta U(\mathrm{~V})$ is the change in cell voltage and $m(\mathrm{~g})$ is the total mass of the electrodes. The energy density, $E_{d}$ and power density $P_{\mathrm{d}}$ of the electrodes were evaluated using Eq. 2 [32] and (3) [1] 
$E_{d}\left(\mathrm{Wh} \mathrm{kg}^{-1}\right)=C_{s p} \times \Delta U^{2} / 28.8$

$P\left(\mathrm{~W} \mathrm{~kg}^{-1}\right)=E_{d} / \Delta t$

\section{RESULTS AND DISCUSSION}

\subsection{Structural, morphological and composition characterization}

The structures of the as-synthesized materials were investigated by XRD and Raman spectroscopy. The XRD patterns (Fig. 1a) show peaks at $51^{\circ}$ (100) and $76^{\circ}$ (110) with an increased intensity identified at the (100) diffraction plane for the AC KOH 2 sample. The peaks represent graphitic diffraction planes, showing that the $\mathrm{AC} \mathrm{KOH} 1$ and $\mathrm{AC} \mathrm{KOH} 2$ materials belong to the class of graphitized carbon. This indicating that the material is comprised of crystals that are crystal phases of the graphitized carbon thus they can be referred to graphitic materials fixed with crystalline carbon owing to the sharp (100) peak while the AC KOH 3 sample contain small crystals that are not well-formed crystal phases and can be referred to as amorphous carbon [33]. The Raman spectra of the activated carbon samples are shown in Fig. 1b. The spectra show the D-band at $1341 \mathrm{~cm}^{-1}$ and the G-band at $1589 \mathrm{~cm}^{-1}$ of the activated carbon which are typical of the disordered amorphous carbons in the $\mathrm{sp}^{2}$ carbon network and the characteristic of the tangential vibrations of the graphitic carbons respectively [12, 34]. The presence of the $D$ and $G$ band present in the Raman spectra indicates the presence of the graphitic carbon in the synthesized materials. The ratio of the intensity of the D and G band $\left(\mathrm{I}_{\mathrm{D}} / \mathrm{I}_{\mathrm{G}}\right)$ is used to determine the degree of graphitization of the materials. In the observed spectra, the ratio of the two bands for $\mathrm{AC} \mathrm{KOH} \mathrm{1,} \mathrm{AC} \mathrm{KOH} 2$ and AC KOH 3 are 0.90, 0.93 and 1.16 respectively, indicating a low degree of graphitic crystalline structure of $\mathrm{AC} \mathrm{KOH} 1$ and $\mathrm{AC}$ $\mathrm{KOH} 2$ and amorphous structure of AC KOH 3 [8, 9, 12, 35]. The Raman spectra for AC KOH 2 was deconvoluted using the Lorentzian curve fitting (Lorentzians) of different combinations of the Raman peaks as presented in Fig. 1c. In Fig. 1c, the G1 and the D1 bands which are common

to all $\mathrm{sp}^{2}$ carbon materials arise from the stretching of the $\mathrm{C}-\mathrm{C}$ bond and the edge of graphene sheet carbon atoms of bulk graphitic materials respectively [36]'[37]. The D2 peak is due to lattice vibration corresponding to that of the $G$ band [38] and the D3 peak arises from the amorphous carbon in interstitial sites of the disturbed lattice of a bulk graphitic material [39] and the D4 peak is due to lattice vibrations corresponding to $\mathrm{sp}^{2}-\mathrm{sp}^{3}$ bonds [40, 41]. A relatively lower intensity of the D3 peak gives information on the amorphous nature of the material. 

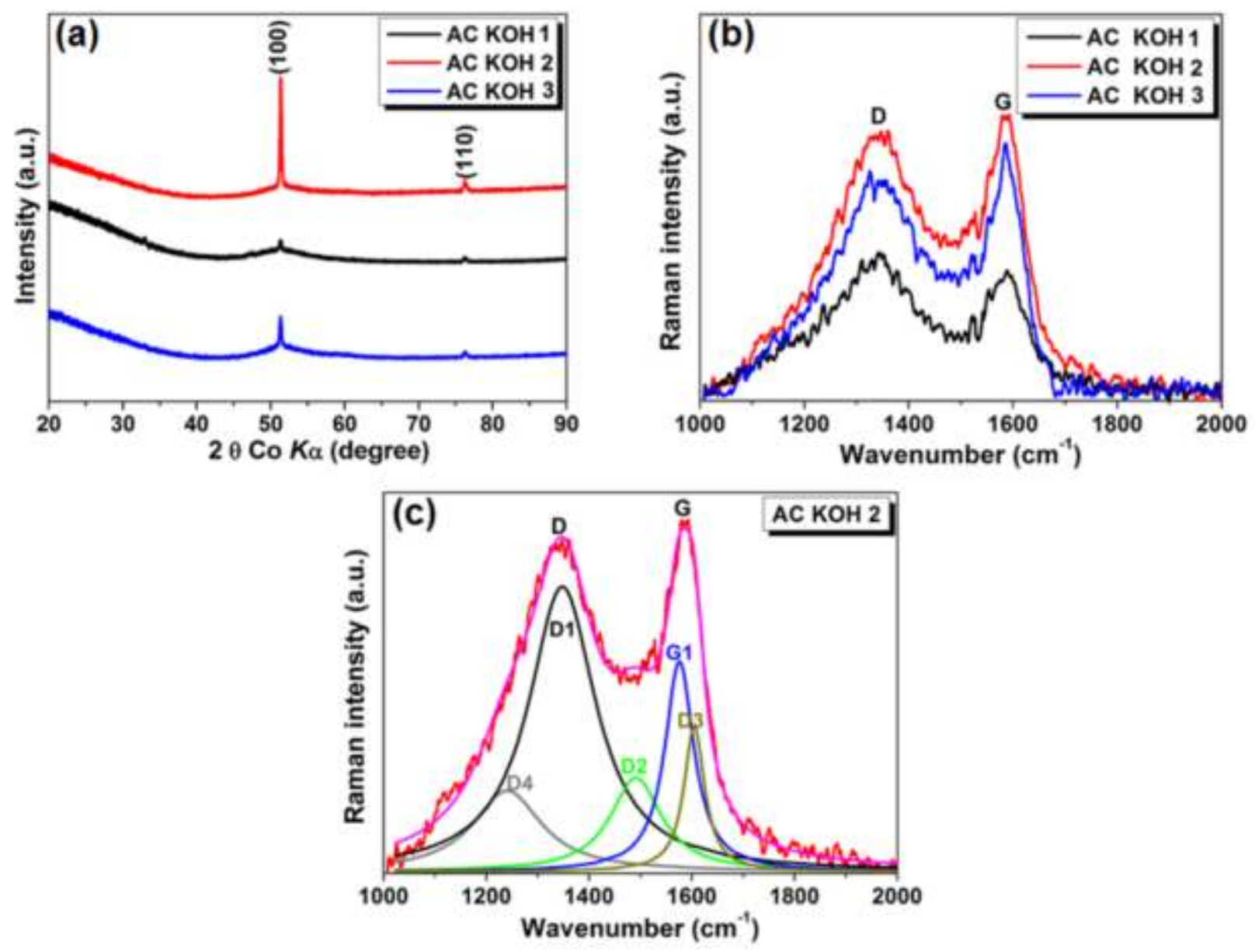

Figure 1 a XRD spectra and b Raman spectra $\left(\lambda_{0}=514 \mathrm{~nm}\right)$ of the AC KOH 1, AC KOH 2 and $\mathrm{AC} \mathrm{KOH} 3$ respectively and $\mathbf{c}$ the corresponding curve fitting (Lorentzians) of different combinations of the Raman peaks for $\mathrm{AC} \mathrm{KOH} 2$.

The SEM micrographs of the as-synthesized samples at low and high magnifications are presented in Fig. 2a to $2 \mathrm{f}$. The micrographs show good 3D interconnected framework structure consisting mainly of porous structure and the characteristic evolution of the pores and structures of the materials studied at the same carbonization temperature of $800{ }^{\circ} \mathrm{C}$. The structural transformation is as a result of the systematic increase of the $\mathrm{KOH}$ activation concentration. Adjustment of the activation agent concentration $(\mathrm{KOH})$ is necessary because it is an important factor in improving the pore size and structure of the carbon thereby achieving a good nanostructured material which ultimately affects the electrochemical performance 

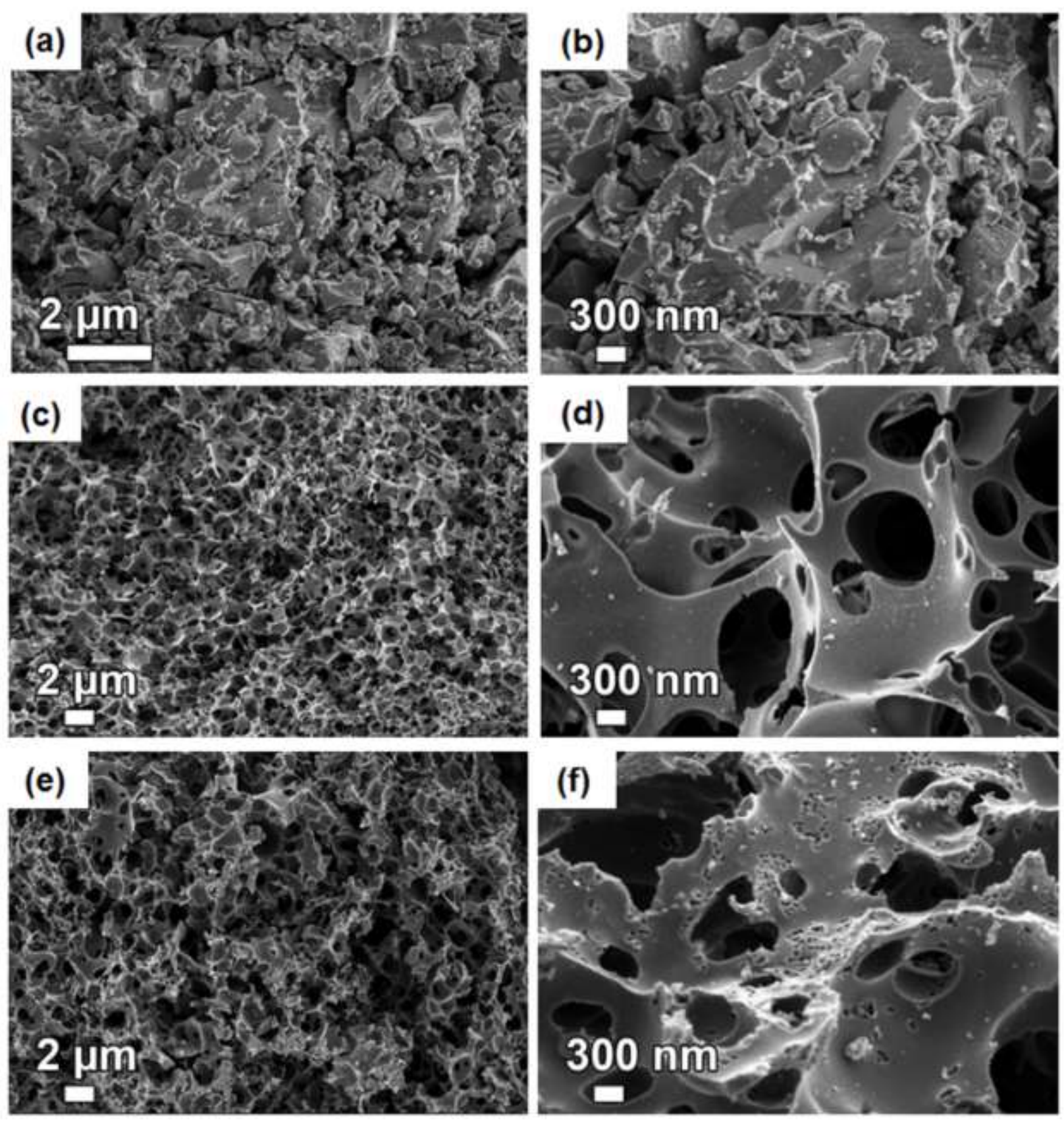

Figure 2 SEM micrographs showing low and high magnifications of a, b AC KOH 1, c, d AC $\mathrm{KOH} 2$ and e, f $\mathrm{AC} \mathrm{KOH} 3$.

of the as-synthesized material $[23,24,28]$. The high magnifications of the micrographs show an uneven porous surface of the material activated with a mass ratio of 1:1 (AC KOH 1) (Fig. 2b). 
Figure $2 \mathrm{~d}$ shows an uneven well-defined and clear porous surface of the material synthesized with a mass ratio of 1:2 ( $\mathrm{AC} \mathrm{KOH} 2)$ and Fig. $2 \mathrm{f}$ shows an uneven porous and perforated surface of the material synthesized with a mass ratio of 1:3 (AC KOH 3). The structure of the latter might be due to the etching effect of $\mathrm{KOH}$ [20]. The activation mostly commences with the reaction shown in Eq. 4 below. The $\mathrm{K}_{2} \mathrm{CO}_{3}$ can decompose into $\mathrm{CO}_{2}$ and $\mathrm{K}_{2} \mathrm{O}$ and can proceed through a reduction reaction by carbon to produce $\mathrm{K}$ at temperatures exceeding $700{ }^{\circ} \mathrm{C}$, and waning completely at approximately $800{ }^{\circ} \mathrm{C}$ generating more porous carbon network $[23,33$, 35].

$6 \mathrm{KOH}+2 \mathrm{C} \rightarrow 2 \mathrm{~K}+3 \mathrm{H}_{2}+2 \mathrm{~K}_{2} \mathrm{CO}_{3}$

$\mathrm{K}_{2} \mathrm{CO}_{3} \rightarrow \mathrm{K}_{2} \mathrm{O}+\mathrm{CO}_{2}$

$\mathrm{C}+\mathrm{K}_{2} \mathrm{O} \rightarrow 2 \mathrm{~K}+\mathrm{CO}$

The structure of the AC KOH 2 material was further investigated using high-resolution transmission electron microscopy (HRTEM). It is worth noting that under electrochemical measurements the $\mathrm{AC} \mathrm{KOH} 2$ material showed high electrochemical performance compared to $\mathrm{AC} \mathrm{KOH} 1$ and $\mathrm{AC} \mathrm{KOH} 3$ materials hence it was further investigated using HRTEM. Figure 3a and $3 \mathrm{~b}$ show low and high-resolution HRTEM micrographs of AC KOH 2 material, respectively. The HRTEM micrograph in Fig. 3a shows a porous microstructure of the material consisting mainly of tightly curled disordered carbon layers (sheet-like morphology). In high-resolution HRTEM micrograph (Fig. 3b), lattice fringes are not observable suggesting that the material is mostly amorphous which is in agreement with the observed selected-area electron diffraction (SAED) pattern (Fig. 3c), which exhibits halo ring with few detectable diffraction spots indicating poor crystallinity of the material. 

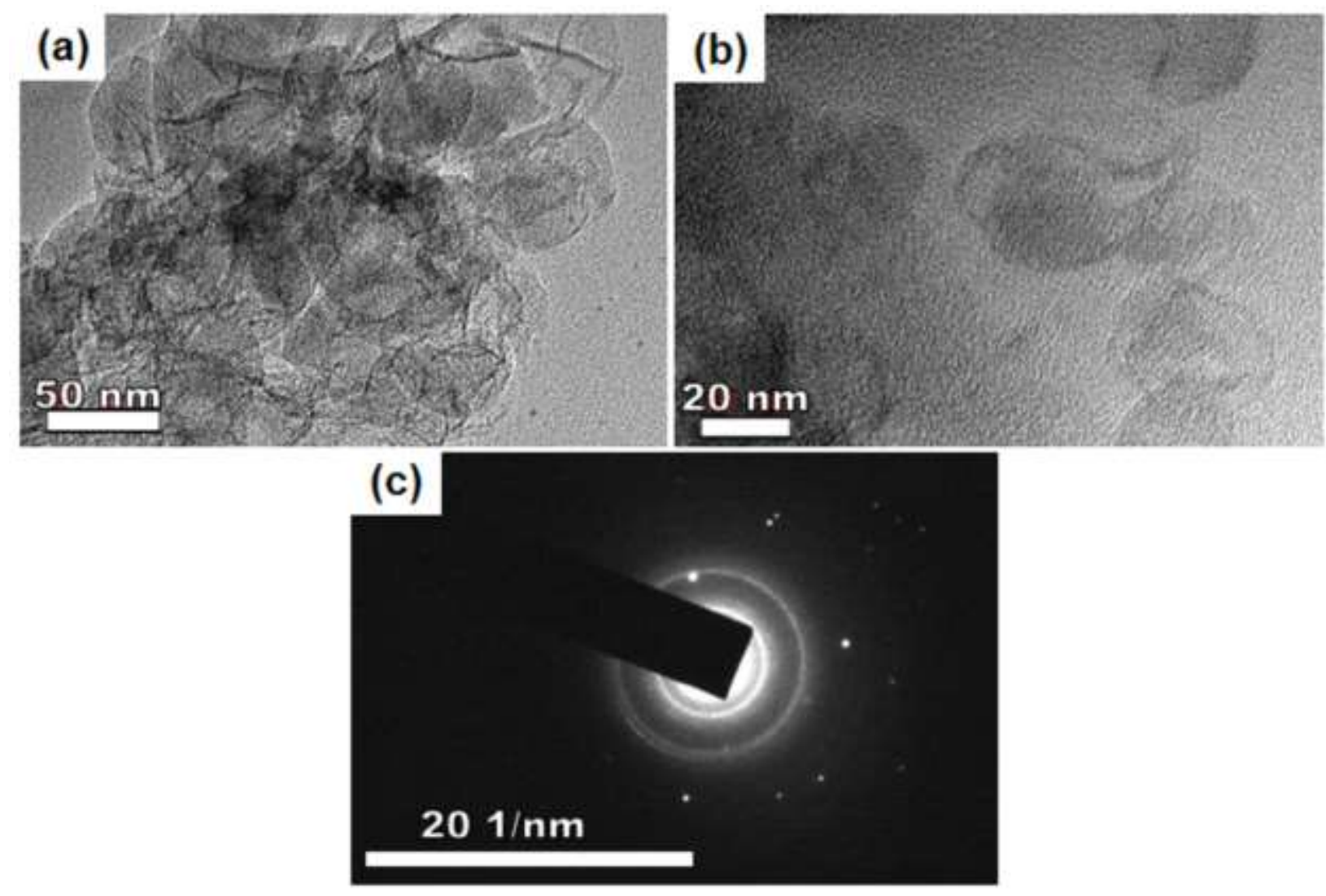

Figure 3a and b Low and high-resolution HRTEM micrographs of AC KOH 2 material respectively, and $\mathbf{c}$ the corresponding selected-area electron diffraction (SAED) pattern.

The EDS spectra for the as-synthesized ACs are presented in Fig. 4. The elemental compositions of the samples are summarized in table 1. The AC materials show a high percentage of carbon followed by oxygen which could originate from the surface functional group present in the sample. The small percentage of chlorine present in the samples might be a contribution from the Embed 812 Epoxy Resin used in the sample preparation prior to EDS analysis. 


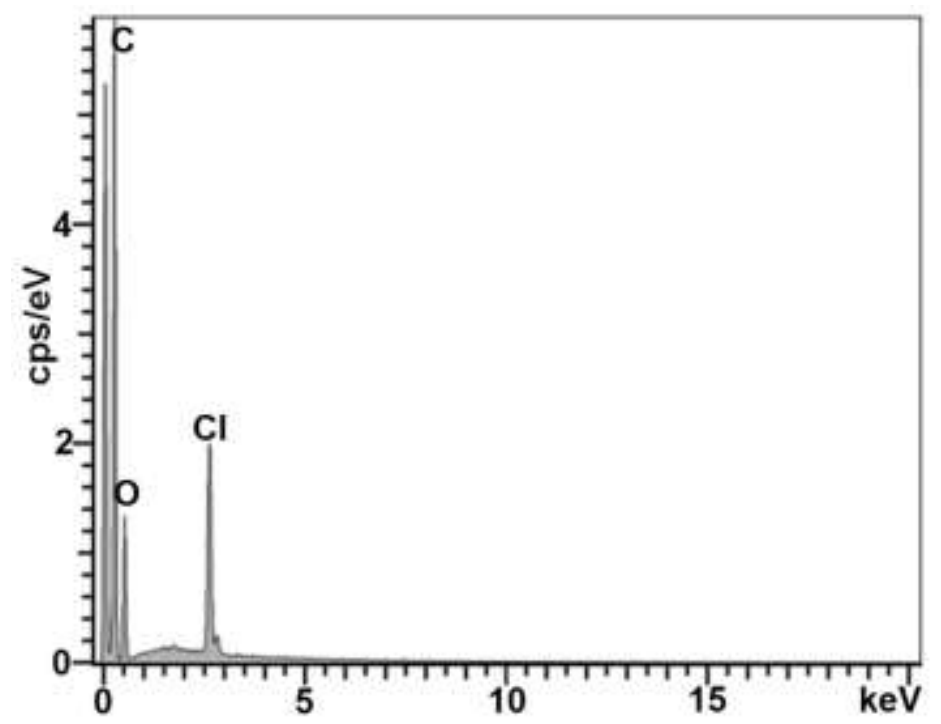

Figure 4 EDS spectra for as-synthesized AC KOH 2 sample.

Table 1 Summary of the elemental compositions of as-synthesized samples.

\begin{tabular}{|c|c|c|c|}
\hline Samples & C (wt \%) & O (wt \%) & Cl (wt \%) \\
\hline AC KOH 1 & 69.47 & 25.16 & 5.37 \\
\hline AC KOH 2 & 72.69 & 21.57 & 5.73 \\
\hline AC KOH 3 & 70.75 & 23.26 & 5.99 \\
\hline
\end{tabular}

The porosity of the samples were investigated using the $\mathrm{N}_{2}$ isotherms studied at $-196{ }^{\circ} \mathrm{C}$. Figure 5a and 5b show typical type IV with $\mathrm{H} 4$ hysteresis loops signifying complex materials comprising micropores and mesopores with relative pressure $\left(\mathrm{P} / \mathrm{P}_{\mathrm{o}}\right)$ range of 0.01 to 1.0 . A summary of the structural and textural properties are presented in Table 2. AC KOH 2 sample showed the highest specific surface area (SSA) and the smallest particle size. Figure 4c shows that increasing the $\mathrm{KOH}$ concentration enhanced the surface area of the carbon. However, a decrease in the BET SSA and an increase in the particle size can be observed for the AC KOH 3 sample when the $\mathrm{KOH}$ concentration was increased further, indicating a correlation between pore microstructures and activation parameters including $\mathrm{KOH}$ mass ratio [20, 24]. The pore size distribution (PSD) was analyzed with Barret-Joyner-Halenda (BJH) method from the desorption branch showing PSD of the samples ranging from 2.0 to $4.2 \mathrm{~nm}$. 

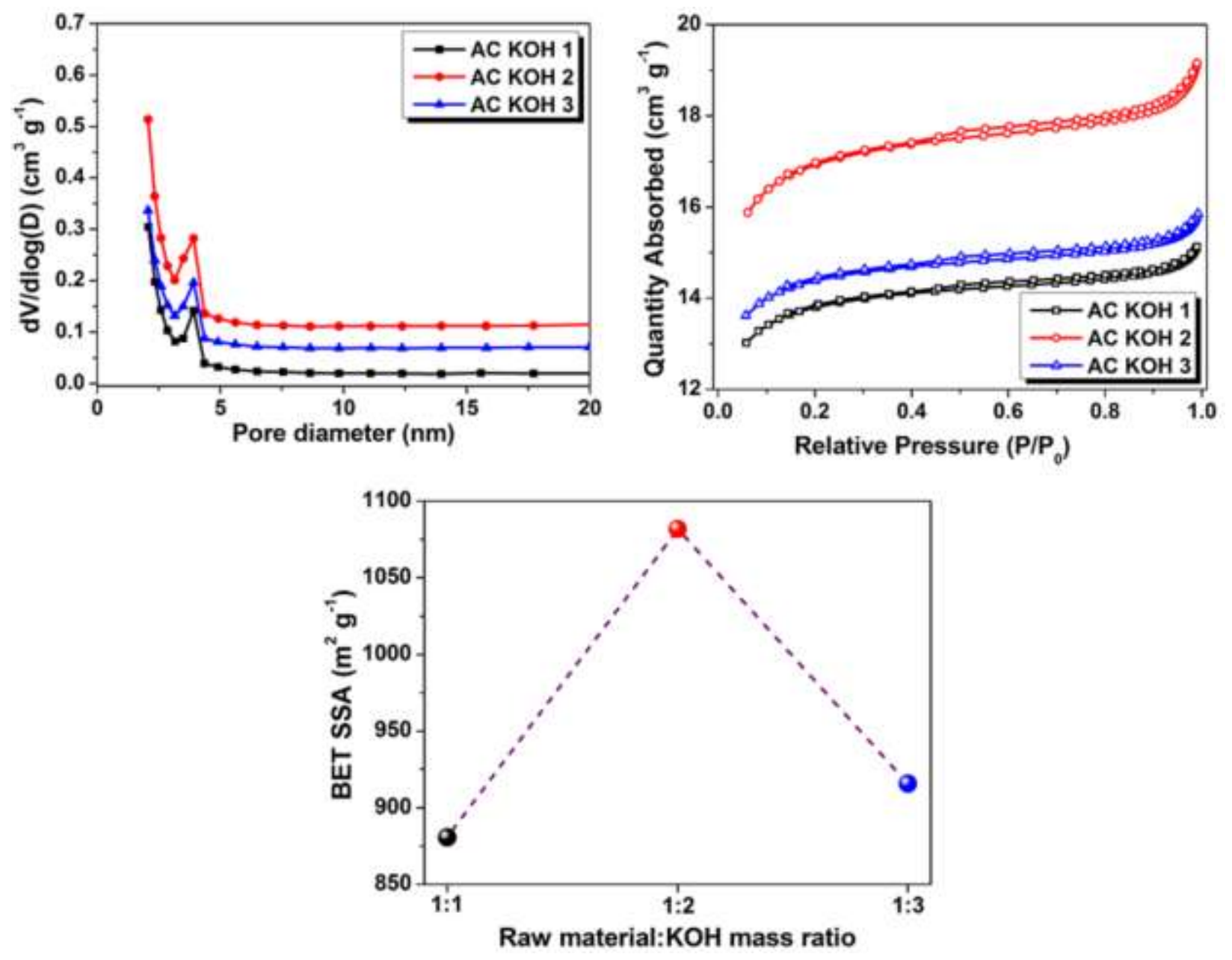

Figure 5 a A plot of pore size distribution of $\mathrm{AC} \mathrm{KOH} \mathrm{1,} \mathrm{AC} \mathrm{KOH} 2$ and $\mathrm{AC} \mathrm{KOH} 3 \mathbf{b ~ N}_{2}$ adsorption-desorption isotherms of AC $\mathrm{KOH} \mathrm{1,} \mathrm{AC} \mathrm{KOH} 2$ and $\mathrm{AC} \mathrm{KOH} \mathrm{3,} \mathbf{c}$ A plot of BET SSA as a function of raw material: $\mathrm{KOH}$ activation mass ratio. 
Table 2 Textural and porosity properties of porous AC samples.

\begin{tabular}{|c|c|c|c|c|}
\hline Samples & $\begin{array}{c}\text { Surface } \\
\text { area }\left(\mathbf{m}^{\mathbf{2}} \mathbf{g}^{\mathbf{- 1}}\right)\end{array}$ & $\begin{array}{c}\text { Micropore Volume } \\
\left(\mathbf{c m}^{\mathbf{3}} \mathbf{g}^{\mathbf{- 1}}\right)\end{array}$ & $\begin{array}{c}\text { Cummulative Volume }^{\mathbf{2}} \\
\left(\mathbf{c m}^{\mathbf{3}} \mathbf{g}^{\mathbf{- 1}}\right)\end{array}$ & $\begin{array}{c}\text { Pore diameter }^{\mathbf{3}} \\
(\mathbf{n m})\end{array}$ \\
\hline AC KOH 1 & 881 & 0.40 & 0.52 & 3.8 \\
\hline AC KOH 2 & 1082 & 0.47 & 0.66 & 4.1 \\
\hline AC KOH 3 & 916 & 0.42 & 0.54 & 4.0 \\
\hline
\end{tabular}

\footnotetext{
${ }^{1}$ t-Plot micropore volume

${ }^{2}$ BJH Desorption cumulative pores between $100 \mathrm{~nm}$ and 300,000 $\mathrm{nm}$ diameter

${ }^{3} \mathrm{BJH}$ desorption average pore diameter (4V/A)
}

\subsection{Electrochemical measurements}

The CV curves of the electrode materials ( $\mathrm{AC} \mathrm{KOH} \mathrm{1,} \mathrm{AC} \mathrm{KOH} 2$ and $\mathrm{AC} \mathrm{KOH} \mathrm{3)} \mathrm{tested} \mathrm{in}$ the typical three-electrode system in $1 \mathrm{M} \mathrm{Na}_{2} \mathrm{SO}_{4}$ neutral electrolyte at a scan rate of $50 \mathrm{mVs}^{-1}$ are presented in Fig. 6a. The CV curves show rectangular shapes both in the positive and negative potential windows which are characteristic of the double layer capacitive behavior of the material. The $\mathrm{CV}$ curves show different current responses within the positive and negative voltage windows of -0.8 to $0 \mathrm{~V}$ and 0 to $0.8 \mathrm{~V}$ vs. $\mathrm{Ag} / \mathrm{AgCl}$ for the samples, and the $\mathrm{CV}$ curve for $\mathrm{AC} \mathrm{KOH} 2$ displays better current response compared to $\mathrm{AC} \mathrm{KOH} 1$ and $\mathrm{AC} \mathrm{KOH} \mathrm{3.} \mathrm{The} C_{\text {sp }}$ for AC $\mathrm{KOH} 2$ sample is $90.6 \mathrm{~F} \mathrm{~g}^{-1}$ in the positive and $100.6 \mathrm{~F} \mathrm{~g}^{-1}$ in the negative potential respectively. The unequal capacitances might be because the voltage where the electrode material and /or electrolyte start to discharge relative to the equipotential, which is the potential of the positive and negative electrodes of the device at zero voltage, are not always symmetrical for the positive and negative electrodes $[14,16]$. The AC KOH 2 material was further tested in the three-electrode system in working potential windows of 0 to $-0.9 \mathrm{~V}$ and 0 to $0.9 \mathrm{~V}$ at $50 \mathrm{mV}$ $\mathrm{s}^{-1}$ in $1 \mathrm{M} \mathrm{Na}_{2} \mathrm{SO}_{4}$ and two other electrolytes, $1 \mathrm{M} \mathrm{NaNO}_{3}$ and $1 \mathrm{M} \mathrm{Li}_{2} \mathrm{SO}_{4}$, as shown in Fig. $6 \mathrm{~b}$. The CV curves show similar rectangular curves in all three electrolytes, indicating a typical reversible EDLC behavior of the material in the different electrolytes. However, a better current response is observed in the $\mathrm{CV}$ curve for the electrode material tested in $1 \mathrm{M} \mathrm{Na}_{2} \mathrm{SO}_{4}$. It is clear 
from both Fig. 6a and $6 \mathrm{~b}$ that sample denoted as $\mathrm{AC} \mathrm{KOH} 2$ in the $1 \mathrm{M} \mathrm{Na}_{2} \mathrm{SO}_{4}$ electrolyte shows the best electrochemical performance and hence from now on will concentrate on these two parameters for the two-electrode device.
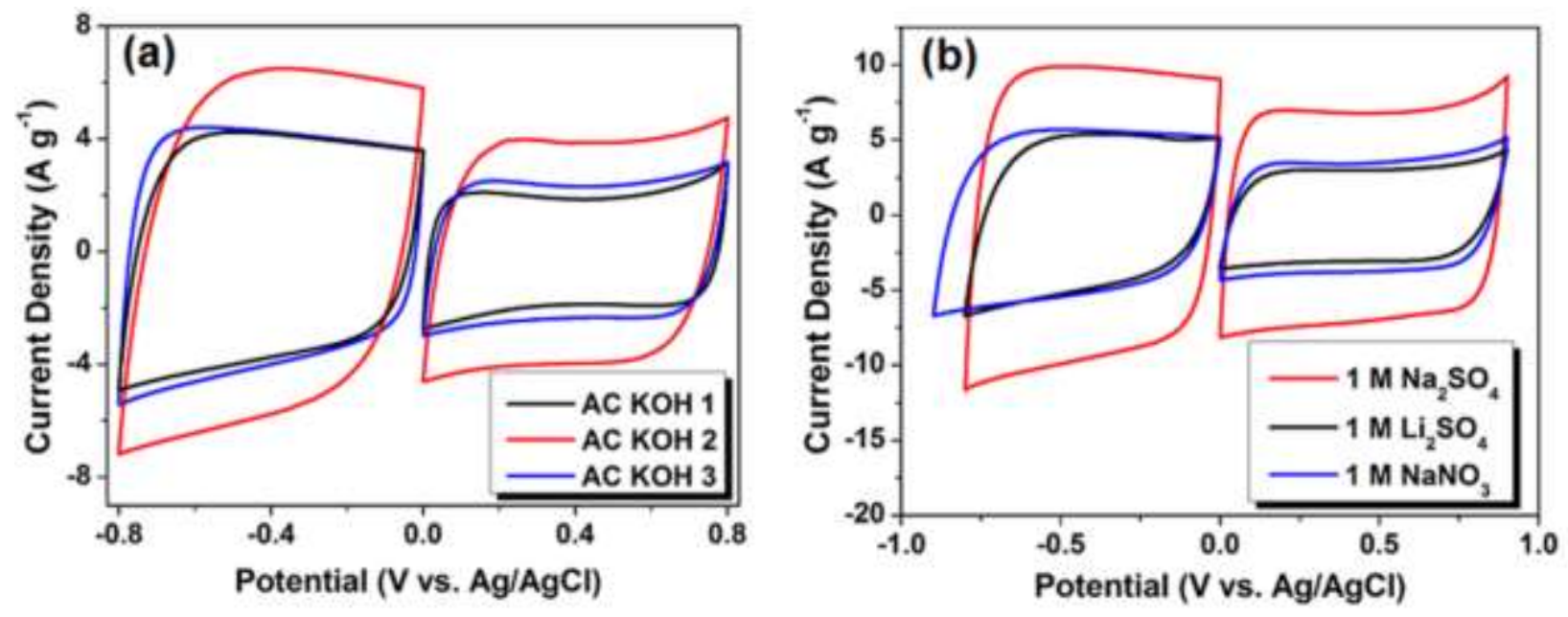

Figure 6 Three electrode measurements: a CV curves for AC KOH 1, AC KOH 2 and AC KOH 3 in -0.8 to $0 \mathrm{~V}$ and 0 to $0.8 \mathrm{~V}$ potential windows at $50 \mathrm{mVs}^{-1}$ and $\mathbf{b} \mathrm{CV}$ curves of $\mathrm{AC} \mathrm{KOH} 2$ at potential windows of 0 to $-0.9 \mathrm{~V}$ and 0 to $0.9 \mathrm{~V}$ at $50 \mathrm{mVs}^{-1}$ in three different electrolytes.

The CV curves for the two-electrode measurements for the symmetric device assembled from $\mathrm{AC} \mathrm{KOH} 2$ investigated at different working potentials ranging from $1.4 \mathrm{~V}$ to $2.0 \mathrm{~V}$ in $1 \mathrm{M}$ $\mathrm{Na}_{2} \mathrm{SO}_{4}$ to determine the stable potential window of the cell is presented in Fig. 7a. The CV curves exhibit rectangular shape within these potential windows which is typical of electric double layer supercapacitors indicating very quick charge/ion transport. The CVs show good stability within this operating voltage. However, above $1.8 \mathrm{~V}$, the anodic current leap is observed indicating gas or oxygen evolutions as the potential tends to $2 \mathrm{~V}$ [14]. However, the functional groups can enhance the ion adsorption and hydrophilicity resulting in quick charge transport within the porous network of the carbon material. Thus, $1.8 \mathrm{~V}$ is a more stable voltage for the electrode material because no current leap is observed for this potential. Neutral electrolyte could operate up to $2.0 \mathrm{~V}$ because of the presence of $\mathrm{H}^{+}$and $\mathrm{OH}^{-}$in low amounts relative to those of acidic and alkaline electrolytes $[1,16]$. Also, Neutral electrolytes are able to achieve higher or extended voltage window of up to $2.0 \mathrm{~V}$ than acid and alkaline electrolytes because of their $\mathrm{pH}$, strong ion solvation and high over-potential for di-hydrogen evolution at the negative electrode 
[16]. Figure $7 \mathrm{~b}$ and $7 \mathrm{c}$ show the $\mathrm{CV}$ curves of the two electrode cell within the potential window of 0.0 to $1.8 \mathrm{~V}$ at scan rates of 10 to $100 \mathrm{mV} \mathrm{s}^{-1}$ and at high scan rates of 200 to $2000 \mathrm{mV} \mathrm{s}^{-1}$ respectively. The $\mathrm{CV}$ curves maintain rectangular shapes with symmetric cathodic and anodic current responses even at very high scan rates indicating quick charge transport which is as a result of the low equivalent series resistance $\left(R_{\mathrm{es}}\right)$ of the electrodes and is characteristic of highly capacitive and reversible electrochemical performance of the as-synthesized material [14, 42]. The galvanostatic charge/discharge (GCD) measurements performed at 0.5 to $5 \mathrm{~A} \mathrm{~g}^{-1}$ are presented in Fig. 7d. A linear charge/discharge curve is observed which is typical of an ideal EDLC with reversible anodic and cathodic ionic transport. A good rate capability is indicated by the cell as only a slight decrease in capacitance is observed at the different current densities. A $C_{\mathrm{SP}}$ of $166 \mathrm{~F} \mathrm{~g}^{-1}$ is observed for the symmetric cell at $0.5 \mathrm{~A} \mathrm{~g}^{-1}$ and is maintained at $133 \mathrm{~F} \mathrm{~g}^{-1}$ as the current density is increased to $5 \mathrm{~A} \mathrm{~g} \mathrm{~g}^{-1}$, displaying $80 \%$ capacitance retention of the symmetric device with increasing current density. 

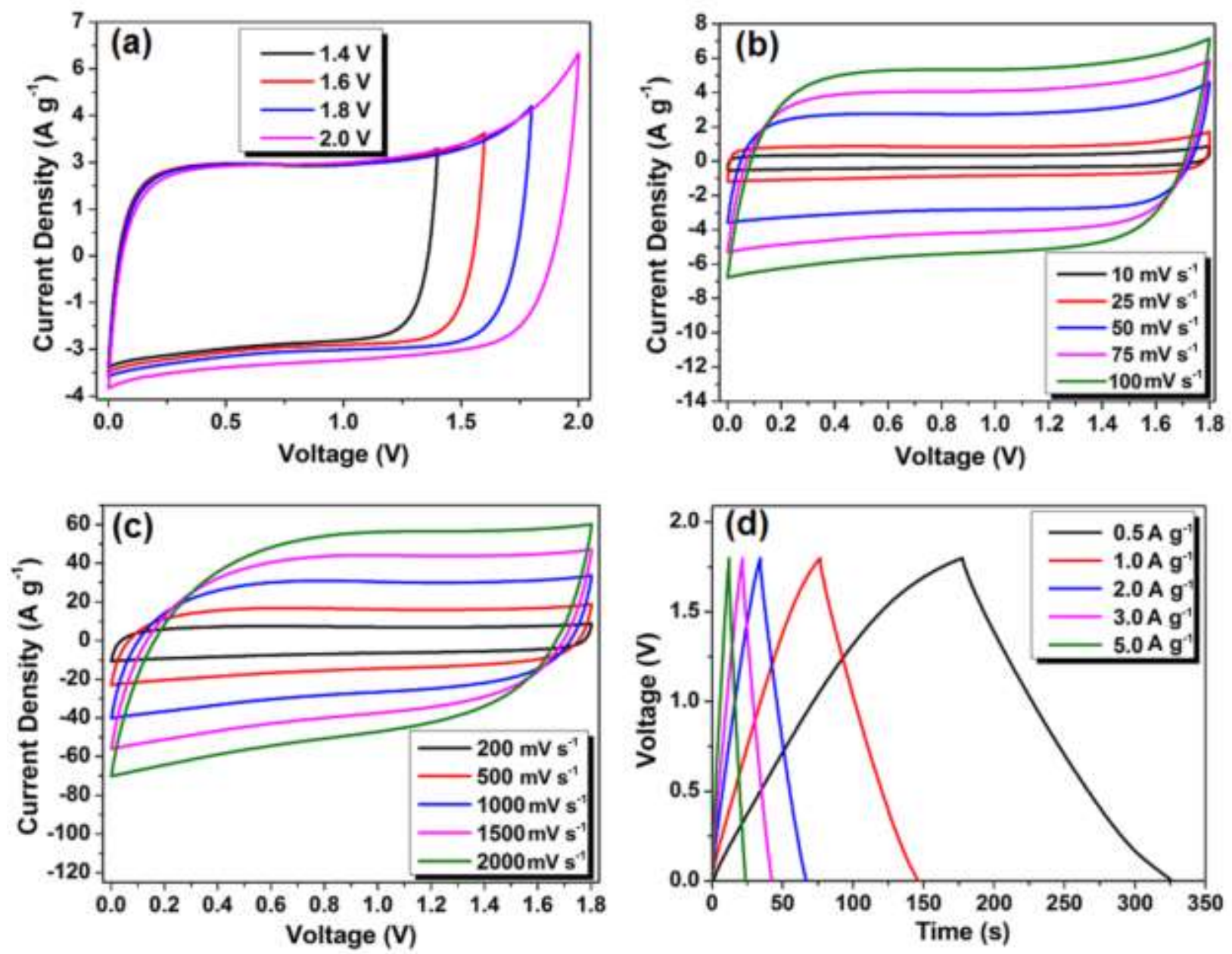

Figure 7 a $\mathrm{CV}$ curves of $\mathrm{AC} \mathrm{KOH} 2$ device at $50 \mathrm{mVs}^{-1}$ at different potential windows in $1 \mathrm{M}$ $\mathrm{Na}_{2} \mathrm{SO}_{4}, \mathbf{b} \mathrm{CV}$ curves of $\mathrm{AC} \mathrm{KOH} 2$ at scan rates ranging from 10 to $100 \mathrm{mVs}^{-1}, \mathbf{c ~ C V}$ curves of $\mathrm{AC} \mathrm{KOH} 2$ at high scan rates ranging from 200 to $2000 \mathrm{mVs}^{-1}$, d CD curves of AC KOH 2 symmetric device at $0.5 \mathrm{~A} \mathrm{~g}^{-1}$ to $5 \mathrm{~A} \mathrm{~g}^{-1}$ in $1 \mathrm{M} \mathrm{Na}_{2} \mathrm{SO}_{4}$.

The energy and power densities of the symmetric device were calculated from Eq. 2 and Eq. 3. The $C_{\mathrm{SP}}$ as a function of current density was calculated using Eq. 2. The Ragone plot which relates the energy and power densities of the symmetric device are presented in Fig. 8. The symmetric device displays a high energy density of $18.6 \mathrm{~W} \mathrm{~h} \mathrm{~kg}$-1 and power density of 449.4 $\mathrm{W} \mathrm{kg}^{-1}$ at a current density of $0.5 \mathrm{~A} \mathrm{~g}^{-1}$. This work shows superior electrochemical performance as compared to other biomass-derived activated carbon [1, 16, 27-31, 35, 43-45]. A comparison of this work with other previous reports is presented in table 3. The excellent performance of this device can be attributed to the high specific surface area, high pore volume 
and large mesopore volume and well defined pore size distribution which boost proper ion transfer within the electrolyte at higher current densities which are necessary for EDLCs to achieve high power delivery rate and high storage capacity and also on the ability of the material to work within the positive and negative potential windows thereby enhancing the potential range of the material in the symmetric device $[23,31,43]$.

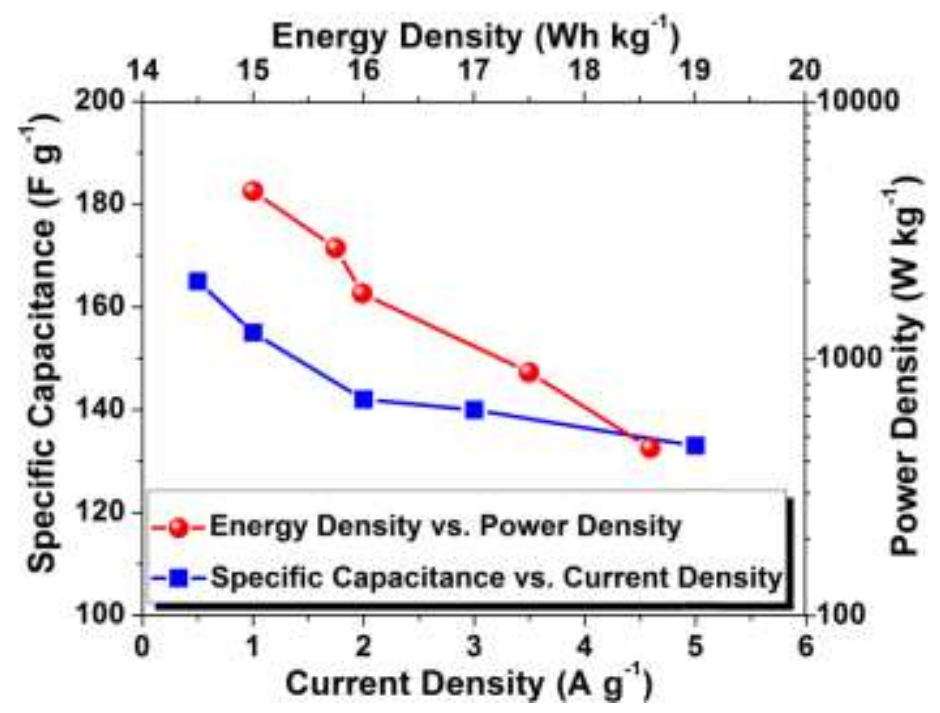

Figure 8 Specific capacitance as a function of current density, and the energy density as a function of power density (Ragone plot) for the symmetric device. 
Table 3 Electrochemical performance comparison of activated carbon derived from different precursors.

\begin{tabular}{|c|c|c|c|c|c|c|c|c|}
\hline Precursor & $\begin{array}{c}\text { Activation } \\
\text { agent }\end{array}$ & $\begin{array}{c}\mathrm{S}_{\mathrm{BET}} \\
\left(\mathrm{m}^{2} \mathrm{~g}^{-1}\right)\end{array}$ & $\begin{array}{c}\text { Voltage } \\
\text { (V) }\end{array}$ & $\begin{array}{c}\text { Specific } \\
\text { capacitance } \\
\left(\mathbf{F ~ g}^{-1}\right)\end{array}$ & $\begin{array}{c}\text { Current } \\
\text { density } \\
\left(\mathrm{A} \mathrm{g}^{-1}\right)\end{array}$ & Electrolyte & $\begin{array}{c}\text { Energy } \\
\text { density } \\
\left(\mathbf{W} \mathbf{h ~ K g}^{-1}\right)\end{array}$ & Ref. \\
\hline Pine cone & $\mathrm{KOH}$ & 1515 & 2.0 & 137 & 0.1 & $1 \mathrm{M} \mathrm{Na}_{2} \mathrm{SO}_{4}$ & 19 & 1 \\
\hline Pine Cone & $\mathrm{KOH}$ & 1515 & 1.0 & 90 & 0.1 & $1 \mathrm{M} \mathrm{Na}_{2} \mathrm{SO}_{4}$ & - & 35 \\
\hline $\begin{array}{l}\text { Coconut } \\
\text { shell }\end{array}$ & $\overline{\mathrm{ZnCl}_{2}}$ & 2440 & 0.7 & 246 & 0.25 & $0.5 \mathrm{H}_{2} \mathrm{SO}_{4}$ & 7.6 & 28 \\
\hline $\begin{array}{l}\text { Tree bark } \\
\text { biomass }\end{array}$ & $\mathrm{KOH}$ & 1018 & 0.6 & 114 & 0.3 & $\begin{array}{c}-1 \mathrm{M} \\
\mathrm{Na}_{2} \mathrm{SO}_{4}\end{array}$ & - & 45 \\
\hline $\begin{array}{l}\text { Coconut } \\
\text { leaves }\end{array}$ & - & 492.9 & 1.0 & 133 & 0.2 & $6 \mathrm{M} \mathrm{KOH}$ & - & 29 \\
\hline $\begin{array}{l}\text { Rubber } \\
\text { wood saw } \\
\text { dust }\end{array}$ & - & 913 & 1.0 & 138 & & $\mathrm{H}_{2} \mathrm{SO}_{4}$ & 2.63 & 46 \\
\hline $\begin{array}{l}\text { Pistachio } \\
\text { nutshells }\end{array}$ & $\mathrm{KOH}$ & 1069 & 1.1 & 261 & 0.2 & $6 \mathrm{M} \mathrm{KOH}$ & 10 & 30 \\
\hline $\begin{array}{l}\text { Sunflower } \\
\text { seed shell }\end{array}$ & $\mathrm{KOH}$ & 2584 & 0.9 & 311 & 0.25 & $3 \mathrm{M} \mathrm{KOH}$ & 4.8 & 27 \\
\hline $\begin{array}{l}\text { Cork } \\
\text { (Quercus } \\
\text { Suber) }\end{array}$ & КОH & 1081 & 1.8 & 166 & 0.5 & $\begin{array}{c}1 \mathrm{M} \\
\mathrm{Na}_{2} \mathrm{SO}_{4}\end{array}$ & 18.6 & $\begin{array}{r}\text { This } \\
\text { work }\end{array}$ \\
\hline
\end{tabular}

The stability of the symmetric device was investigated over 5000 charge/discharge cycles and the device displays $\sim 100 \%$ capacitance retention at the end of the charge/discharge cycle (Fig. 9a). Also, stability test based on voltage holding was used to study the long-term stability of the symmetric device. Figure $9 \mathrm{~b}$ shows the curve of voltage holding over a time duration of $200 \mathrm{~h}$. The floating time is based on periodic potentiostatic mode and sequential GCD at $1 \mathrm{~A} \mathrm{~g}^{-1}$. The floating and galvanostatic processes are reiterated for a total of $200 \mathrm{~h}$. The floating shows a significant effect on the capacitive behavior of the devices which decreases in the first $40 \mathrm{~h}$ of floating before stabilizing at $\sim 130 \mathrm{Fg}^{-1}$ for the rest of the floating time, with capacitance retention of $85 \%$ over $200 \mathrm{~h}$. The decrease in capacitance could be as a result of the wearing of 
the surface functional group which could facilitate ion transport within the electrode material [46].
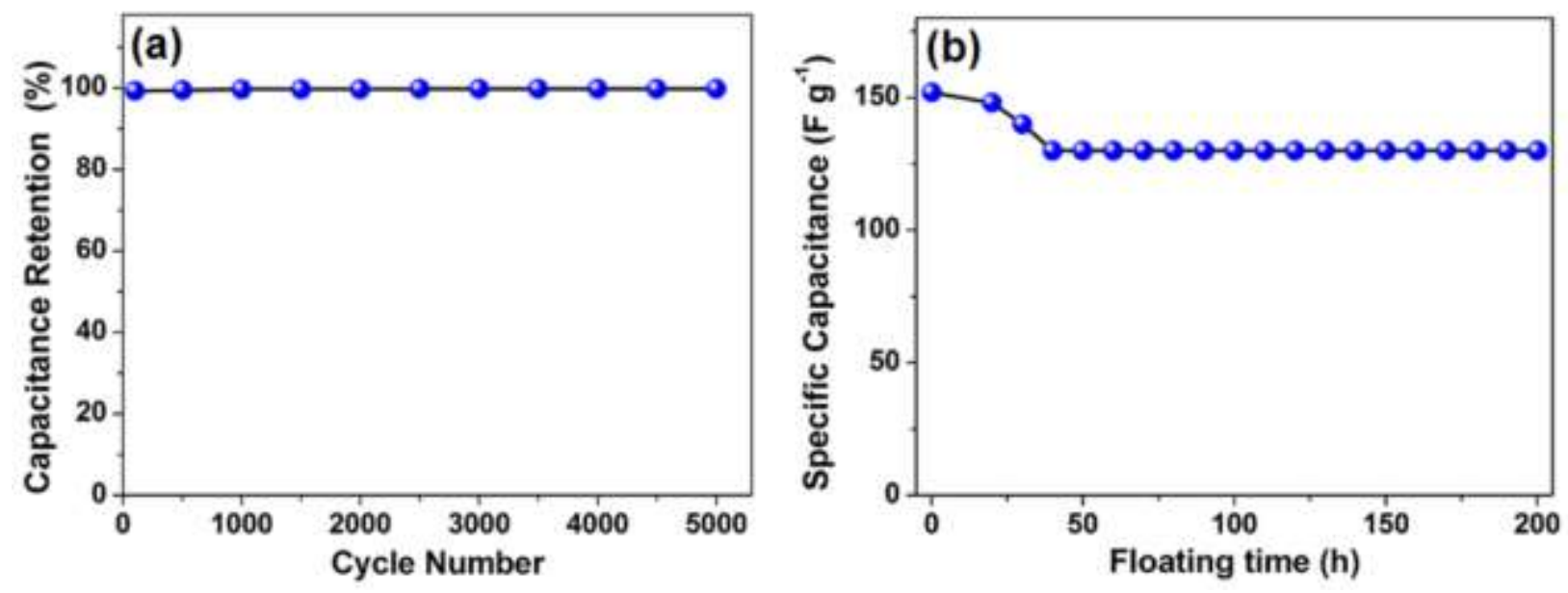

Figure 9 Stability test of AC KOH 2 sample: a Capacitance retention as a function of a number of cycles and $\mathbf{b}$ specific capacitance as a function of floating time.

Electrochemical impedance spectroscopy (EIS) measurements were also carried out. Figure 10a shows the Nyquist impedance plot for the EIS measurements analyzed in the frequency range of $100 \mathrm{kHz}-0.01 \mathrm{~Hz}$. The diameter of the arc within the high and middlefrequency region shows the charge transfer resistance $\left(R_{\mathrm{ct}}\right)$ of $1.3 \Omega$. The solution resistance $\left(R_{\mathrm{S}}\right)$ of $0.77 \Omega$ (intercept to the $\mathrm{x}$-axis, see insert to Fig. 10a) was observed from the Nyquist impedance plot with the real $Z^{\prime}$ axis which sums up the resistive components within the device $[46,47]$. The fitting of the Nyquist plot is presented in Fig. 10b with the equivalent circuit (insert to Fig. 10b). The constant phase element $Q$ and the charge transfer resistance $\left(R_{\mathrm{ct}}\right)$ are connected in series with $R_{\mathrm{s}}$. The diffusion element $(W)$, which is in series with the $R_{\mathrm{ct}}$ corresponds to the diffusion from the high to the low-frequency region. Normally, an ideal electrode with mass capacitance $(C)$, at very low frequencies should lead to a vertical line parallel to the $-Z^{\prime \prime}$ axis [46]. However, from Fig.10a, a slight deviation from the ideal behavior is observed which can be as a result of the resistive element linked with $C$. This resistive element termed leakage current is connected in parallel to the mass capacitance. The real and imaginary part of the capacitances as 
a function of frequency $\left(C^{\prime}(\omega)\right.$ and $\left.C^{\prime \prime}(\omega)\right)$ was evaluated using a complex capacitance model and is presented in Fig. 10d. For the electrodes, the value of $C^{\prime}$ at $0.01 \mathrm{~Hz}$ is $0.33 \mathrm{~F}$ which corresponds to the real reachable capacitance of the cell at this frequency. $C^{\prime \prime}$ represents the energy utilized and it also shows the frequency evolution between an ideal capacitive and resistive behavior [48]. The relaxation time $(\tau)$ evaluated from $\tau=1 / \omega_{\max }=1 /\left(2 \pi f_{\max }\right)$ is $\sim 0.89 \mathrm{~s}$ corresponding to a frequency of $\sim 1.0 \mathrm{~Hz}$. This relaxation time shows that the energy stored in the cell can be released within $0.89 \mathrm{~s}$. The phase angle as a function of frequency is presented in Fig. 10c. It shows that the phase angle of the cell is $\sim-85^{\circ}$, which is very near to $90^{\circ}$ indicating a complete capacitive behavior of the electrodes.
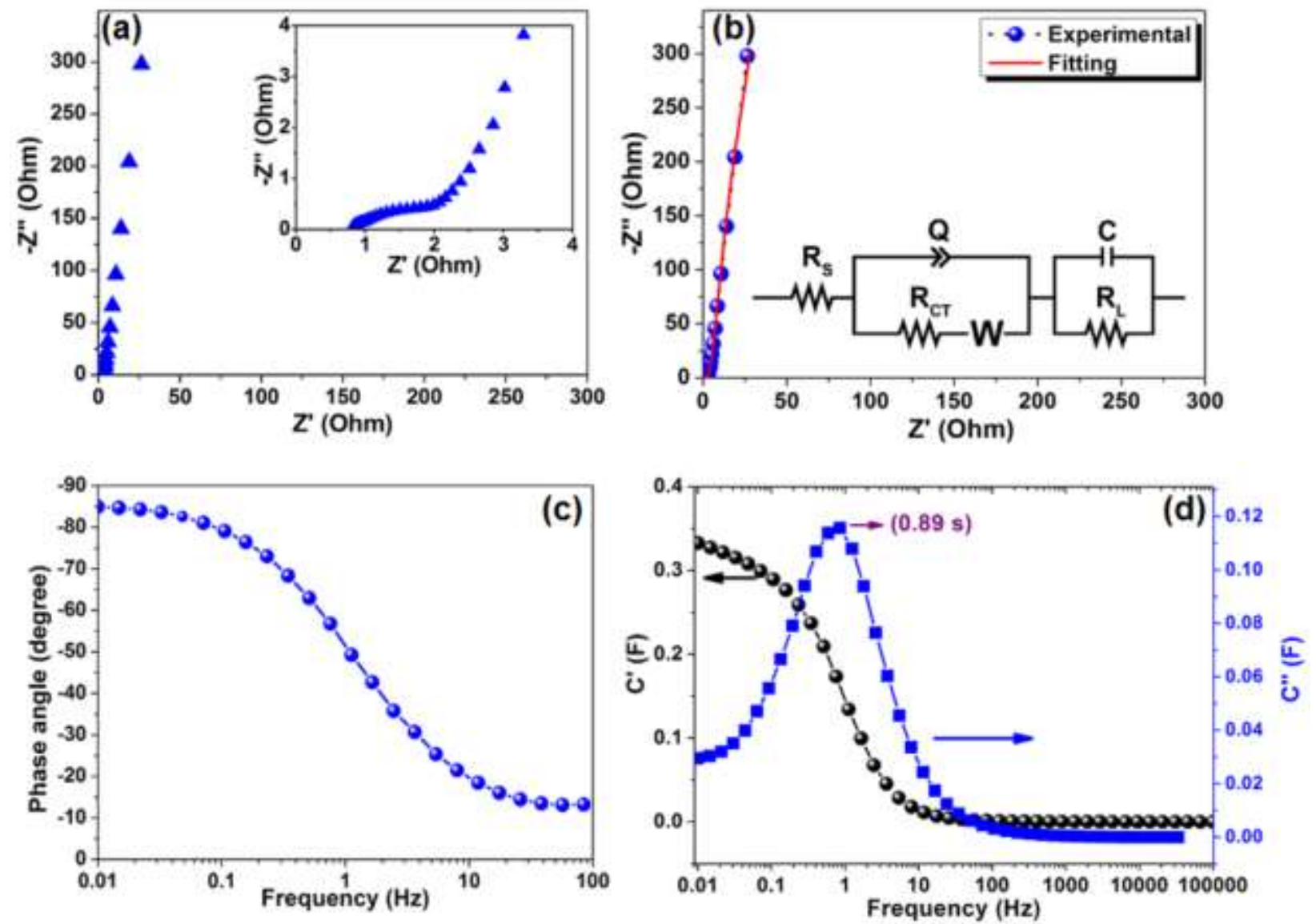

Figure 10 a EIS plot, b EIS fitting and equivalent series circuit (inset), c phase angle as a function of frequency and $\mathbf{d}$ real and imaginary plot of capacitance as a function of frequency. 


\section{CONCLUSIONS}

Activated carbon from light weight material Cork (Quercus Suber), has been successfully synthesized using a systematic approach which is environmentally friendly and cost effective. The material shows well-defined and clear porous surface with large surface area and good micropore and mesopore volume. A high specific capacitance of $166 \mathrm{~F} \mathrm{~g}^{-1}$ was obtained at a current density of $0.5 \mathrm{~A} \mathrm{~g}^{-1}$ and was maintained at $133 \mathrm{~F} \mathrm{~g}^{-1}$ as the current density increased to $5.0 \mathrm{~A} \mathrm{~g}^{-1}$ with energy and power densities of $18.6 \mathrm{~W} \mathrm{~h} \mathrm{~kg}^{-1}$ and $449.4 \mathrm{~W} \mathrm{~kg}^{-1}$ respectively for the symmetric device. This device displays good rate capability in the neutral electrolyte. The device also shows excellent stability and without significant degradation after $200 \mathrm{~h}$ of floating time. The results suggest that the material is a potentially excellent material for supercapacitor applications.

\section{ACKNOWLEDGEMENTS}

This work is based on research supported by the South African Research Chairs Initiative (SARChI) of the Department of Science and Technology and the National Research Foundation (NRF) of South Africa (Grant No. 61056). Any opinion, finding and conclusion or recommendation expressed in this material is that of the author(s) and the NRF does not accept any liability in this regard. Faith O. Ochai-Ejeh acknowledges NRF through SARChI in Carbon Technology and Materials, and the department of physics at the University of Pretoria for financial support.

\section{NOTES}

The authors declare no competing financial interest.

\section{REFERENCES}

1. Bello A, Manyala N, Barzegar F, et al (2016) Renewable pine cone biomass derived carbon materials for supercapacitor application. RSC Adv 6:1800-1809. doi: 10.1039/C5RA21708C

2. $\mathrm{Yu}$ G, Hu L, Vosgueritchian M, et al (2011) Solution-Processed Graphene/MnO 2 Nanostructured Textiles for High-Performance Electrochemical Capacitors. Nano Lett 11:2905-2911. doi: $10.1021 / \mathrm{nl} 2013828$

3. Biswal M, Banerjee A, Deo M, Ogale S (2013) From dead leaves to high energy density 
supercapacitors. Energy Environ Sci 6:1249. doi: 10.1039/c3ee22325f

4. Shaikjee A, Coville NJ (2012) The role of the hydrocarbon source on the growth of carbon materials. Carbon N Y 50:3376-3398. doi: 10.1016/j.carbon.2012.03.024

5. Gan JK, Lim YS, Pandikumar A, et al (2015) Graphene/polypyrrole-coated carbon nanofiber core-shell architecture electrode for electrochemical capacitors. RSC Adv 5:12692-12699. doi: 10.1039/C4RA14922J

6. Majeau-Bettez G, Hawkins TR, Strømman AH (2011) Life Cycle Environmental Assessment of Lithium-Ion and Nickel Metal Hydride Batteries for Plug-In Hybrid and Battery Electric Vehicles. Environ Sci Technol 45:4548-4554. doi: 10.1021/es103607c

7. Zhang LL, Zhao XS (2009) Carbon-based materials as supercapacitor electrodes. Chem Soc Rev 38:2520. doi: 10.1039/b813846j

8. Stoller MD, Ruoff RS (2010) Best practice methods for determining an electrode material's performance for ultracapacitors. Energy Environ Sci 3:1294. doi: 10.1039/c0ee00074d

9. Patil DS, Shaikh JS, Dalavi DS, et al (2011) Chemical synthesis of highly stable PVA/PANI films for supercapacitor application. Mater Chem Phys 128:449-455. doi: 10.1016/j.matchemphys.2011.03.029

10. Miller JR, Simon P (2008) Materials science. Electrochemical capacitors for energy management. Science 321:651-2. doi: 10.1126/science.1158736

11. Jain A, Balasubramanian R, Srinivasan MP (2016) Hydrothermal conversion of biomass waste to activated carbon with high porosity: A review. Chem Eng J 283:789-805. doi: 10.1016/j.cej.2015.08.014

12. Gan JK, Lim YS, Pandikumar A, et al (2015) Graphene/polypyrrole-coated carbon nanofiber core-shell architecture electrode for electrochemical capacitors. RSC Adv 5:12692-12699. doi: 10.1039/C4RA14922J

13. Chen H, Hu L, Chen M, et al (2014) Nickel-Cobalt Layered Double Hydroxide Nanosheets for High-performance Supercapacitor Electrode Materials. Adv Funct Mater 24:934-942. doi: 10.1002/adfm.201301747

14. Chae JH, Chen GZ (2012) $1.9 \mathrm{~V}$ aqueous carbon-carbon supercapacitors with unequal electrode capacitances. Electrochim Acta 86:248-254. doi: 10.1016/j.electacta.2012.07.033

15. Peng C, Zhang S, Zhou X, Chen GZ (2010) Unequalisation of electrode capacitances for enhanced energy capacity in asymmetrical supercapacitors. Energy Environ Sci 3:1499. doi: $10.1039 / \mathrm{c} 0 \mathrm{ee} 00228 \mathrm{c}$

16. Demarconnay L, Raymundo-Piñero E, Béguin F (2010) A symmetric carbon/carbon supercapacitor operating at $1.6 \mathrm{~V}$ by using a neutral aqueous solution. Electrochem commun. doi: 
10.1016/j.elecom.2010.06.036

17. An K, Kim W, Park Y, Moon J (2001) Electrochemical properties of high-power supercapacitors using single-walled carbon nanotube electrodes. Adv. Funct.

18. Wang H, Liang Y, Mirfakhrai T, et al Advanced Asymmetrical Supercapacitors Based on Graphene Hybrid Materials.

19. Fan Z, Yan J, Wei T, et al (2011) Asymmetric Supercapacitors Based on Graphene/MnO2 and Activated Carbon Nanofiber Electrodes with High Power and Energy Density. Adv Funct Mater 21:2366-2375. doi: 10.1002/adfm.201100058

20. Sevilla M, Fuertes AB (2016) A Green Approach to High-Performance Supercapacitor Electrodes: The Chemical Activation of Hydrochar with Potassium Bicarbonate. ChemSusChem 9:18801888. doi: $10.1002 /$ cssc. 201600426

21. Wei L, Yushin G (2012) Nanostructured activated carbons from natural precursors for electrical double layer capacitors. Nano Energy 1:552-565. doi: 10.1016/j.nanoen.2012.05.002

22. Wang H, Xu Z, Kohandehghan A, et al (2013) Interconnected carbon nanosheets derived from hemp for ultrafast supercapacitors with high energy. ACS Nano 7:5131-41. doi: $10.1021 / \mathrm{nn} 400731 \mathrm{~g}$

23. Wang J, Kaskel S (2012) KOH activation of carbon-based materials for energy storage. J Mater Chem 22:23710. doi: 10.1039/c2jm34066f

24. Lv Y, Zhang F, Dou Y, et al (2012) A comprehensive study on $\mathrm{KOH}$ activation of ordered mesoporous carbons and their supercapacitor application. J Mater Chem 22:93. doi: $10.1039 / \mathrm{c} 1 \mathrm{jm} 12742 \mathrm{j}$

25. Béguin F, Presser V, Balducci A, Frackowiak E (2014) Carbons and Electrolytes for Advanced Supercapacitors. Adv Mater 26:2219-2251. doi: 10.1002/adma.201304137

26. Bello A, Barzegar F, Madito MJ, et al (2016) Stability studies of polypyrole- derived carbon based symmetric supercapacitor via potentiostatic floating test. Electrochim Acta 213:107-114. doi: 10.1016/j.electacta.2016.06.151

27. Li X, Xing W, Zhuo S, et al (2011) Preparation of capacitor's electrode from sunflower seed shell. Bioresour Technol 102:1118-1123. doi: 10.1016/j.biortech.2010.08.110

28. Jain A, Xu C, Jayaraman S, et al (2015) Mesoporous activated carbons with enhanced porosity by optimal hydrothermal pre-treatment of biomass for supercapacitor applications. Microporous Mesoporous Mater 218:55-61. doi: 10.1016/j.micromeso.2015.06.041

29. Sulaiman KS, Mat A, Arof AK (2016) Activated carbon from coconut leaves for electrical doublelayer capacitor. Ionics (Kiel) 22:911-918. doi: 10.1007/s11581-015-1594-9

30. Xu J, Gao Q, Zhang Y, et al (2014) Preparing two-dimensional microporous carbon from Pistachio 
nutshell with high areal capacitance as supercapacitor materials. Sci Rep 4:845-854. doi: 10.1038/srep05545

31. Barzegar F, Bello A, Fashedemi OO, et al (2015) Synthesis of 3D porous carbon based on cheap polymers and graphene foam for high-performance electrochemical capacitors. Electrochim Acta 180:442-450. doi: 10.1016/j.electacta.2015.08.148

32. Laheäär A, Przygocki P, Abbas Q, Béguin F (2015) Appropriate methods for evaluating the efficiency and capacitive behavior of different types of supercapacitors. Electrochem commun. doi: 10.1016/j.elecom.2015.07.022

33. Zheng X, Lv W, Tao Y, et al (2014) Oriented and Interlinked Porous Carbon Nanosheets with an Extraordinary Capacitive Performance. Chem Mater 26:6896-6903. doi: 10.1021/cm503845q

34. Lee JW, Hall AS, Kim J-D, Mallouk TE (2012) A Facile and Template-Free Hydrothermal Synthesis of $\mathrm{Mn}_{3} \mathrm{O}_{4}$ Nanorods on Graphene Sheets for Supercapacitor Electrodes with Long Cycle Stability. Chem Mater 24:1158-1164. doi: 10.1021/cm203697w

35. Manyala N, Bello A, Barzegar F, et al (2015) Coniferous pine biomass: A novel insight into sustainable carbon materials for supercapacitors electrode. Mater Chem Phys 182:139-147. doi: 10.1016/j.matchemphys.2016.07.015

36. Wang Y, Alsmeyer DC, McCreery RL (1990) Raman spectroscopy of carbon materials: structural basis of observed spectra. Chem Mater 2:557-563. doi: 10.1021/cm00011a018

37. Malard LM, Pimenta MA, Dresselhaus G, Dresselhaus MS (2009) Raman spectroscopy in graphene. Phys Rep 473:51-87. doi: 10.1016/j.physrep.2009.02.003

38. Sadezky A, Muckenhuber H, Grothe H, et al (2005) Raman microspectroscopy of soot and related carbonaceous materials: Spectral analysis and structural information. Carbon N Y 43:1731-1742. doi: 10.1016/j.carbon.2005.02.018

39. Jawhari T, Roid A, Casado J (1995) Raman spectroscopic characterization of some commercially available carbon black materials. Carbon N Y 33:1561-1565. doi: 10.1016/0008-6223(95)00117$\mathrm{V}$

40. Sze S (2001) Raman spectroscopic characterization of carbonaceous aerosols. Atmos Environ 35:561-568. doi: 10.1016/S1352-2310(00)00325-3

41. Dippel B, Jander H, Heintzenberg J (1999) NIR FT Raman spectroscopic study of flame soot. Phys Chem Chem Phys 1:4707-4712. doi: 10.1039/a904529e

42. Jang Y, Jo J, Choi Y-M, et al (2013) Activated carbon nanocomposite electrodes for high performance supercapacitors. Electrochim Acta 102:240-245. doi:

10.1016/j.electacta.2013.04.020

43. Jain A, Xu C, Jayaraman S, et al (2015) Mesoporous activated carbons with enhanced porosity by 
optimal hydrothermal pre-treatment of biomass for supercapacitor applications. Microporous Mesoporous Mater 218:55-61. doi: 10.1016/j.micromeso.2015.06.041

44. Momodu DY, Madito MJ, Barzegar F, et al (2016) Activated Carbon Derived from Tree Bark Biomass for High Performance Electrochemical Capacitors. Meet Abstr MA2016-02:984-984.

45. Taer E, Deraman M, Talib IA, et al (2011) Preparation of a Highly Porous Binderless Activated Carbon Monolith from Rubber Wood Sawdust by a Multi-Step Activation Process for Application in Supercapacitors. Int J Electrochem Sci 6:3301-3315.

46. Barzegar F, Bello A, Momodu D, et al (2016) Preparation and characterization of porous carbon from expanded graphite for high energy density supercapacitor in aqueous electrolyte. J Power Sources 309:245-253. doi: 10.1016/j.jpowsour.2016.01.097

47. Luo J, Jang HD, Huang J (2013) Effect of Sheet Morphology on the Scalability of GrapheneBased Ultracapacitors. ACS Nano 7:1464-1471. doi: 10.1021/nn3052378

48. Taberna PL, Simon P, Fauvarque JF (2003) Electrochemical Characteristics and Impedance Spectroscopy Studies of Carbon-Carbon Supercapacitors. J Electrochem Soc 150:A292. doi: $10.1149 / 1.1543948$ 